\title{
Tax Sanctions from the Authority Perspective
}

\author{
Cindy Fitria Sumuan ${ }^{1}$ \\ Fidiana $^{2}$ \\ ${ }_{1,2}$ Accounting Department, Sekolah Tinggi Ilmu Ekonomi Indonesia Surabaya, Indonesia \\ email: fidiana@stiesia.ac.id
}

DOI: https://doi.org/10.24843/JIAB.2020.v15.i01.p10

\begin{tabular}{l}
$\begin{array}{l}\text { Jurnal Ilmiah Akuntansi } \\
\text { dan Bisnis } \\
\text { (JIAB) }\end{array}$ \\
\hline Volume 15 \\
Issue 1 \\
January 2020 \\
Page 107 - 118 \\
p-ISSN 2302-514X \\
e-ISSN 2303-1018 \\
\hline ARTICLE INFORMATION: \\
\hline Received: \\
04 October 2019 \\
Revised: \\
11 November 2019 \\
Accepted: \\
08 January 2020 \\
\hline
\end{tabular}

\section{INTRODUCTION}

The study of tax compliance is more often highlighted from the behavioral aspect, especially based on theory of reasoned action or from the planned behavior perspective (Fidiana, 2015). While from a social perspective, tax compliance can be formed from the convenience of interaction with the tax authorities (Fidiana, 2015). The convenience of interacting and transacting taxation plays a role in fostering public trust in the tax authority which in turn is able to shape tax-abiding behavior. Willingness to obey thus can be activated without the threat of sanctions and checks so that the target to collect state revenue can be achieved.

Taxes are a source of state revenue, both direct and indirect, originating from the public. The tax can be regarded as an obligation of citizens to finance the implementation of government and development whose implementation is regulated in laws for the purpose of the welfare of the nation and state. The government as tax recipient always tries to fulfill the Indonesian Budget (APBN), as shown in Table 1 below.

Table 1. Indonesian Income Year of 2017 (triliun rupiah)

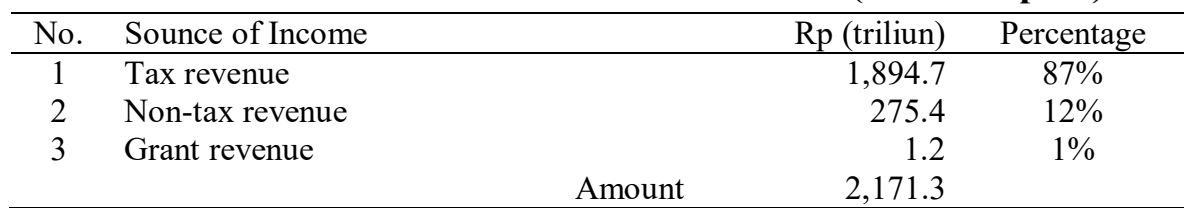

Source: Ministry of Finance, 2017

Table 1 shows that the highest contribution $(87 \%)$ in state revenue comes from tax revenue. However, the target of state revenue derived from taxes has never been reached, as evidenced by the low level of tax compliance (Fidiana, 2015; Manurung, 2013). Table 1 shows that the highest contribution $(87 \%)$ in state revenue comes from tax revenue. This unachieved tax target shows the difficulty of 
achieving state revenue from taxes. Meanwhile, tax authorities have made various efforts to improve tax compliance. In 2015 for example, it was declared a year of guidance for taxpayers and in 2016 it was declared as tax control (Fidiana, 2015).

This government effort began in 1984, through the first tax reform by transforming the official tax collection system into a self-assessment system. The tax authority still has room in the self-assessment system through the supervisory function (Cahyadini et al., 2017; Ningrum \& Ispiyarso, 2016; Rahayu, 2017; Siamena et al., 2017). This function allows the authority to conduct optimal oversight and law enforcement if taxpayers deviate from taxation obligations. Taxpayers who do not carry out their tax obligations in accordance with applicable tax provisions, will be subject to tax sanctions. So, tax sanctions serve as a stimulus for taxpayers to comply with tax rules (Ariani \& Utami, 2016).

The role of tax sanctions in improving tax compliance has been widely studied (Doran, 2009; Ermawati \& Afifi, 2018; Newberry et al., 1993). The study confirmed that tax sanctions can improve tax compliance. High tax sanctions will encourage taxpayers to obey taxes. However, other studies have not been able to confirm tax compliance based on tax sanctions (Lederman, 2005; Masruroh, 2013; Nar, 2015). Some empirical facts do show the high rate of tax evasion (Fidiana, 2015) thus showing that penalties and audits do not always have a deterrent effect to improve compliance (Lederman, 2005). The hostage case is evidence that the fine of the sanction and audit is ignored by the taxpayer. In 2019, the tax authorities have held hostage to several taxpayers who have ignored tax arrears. In August, the Regional Office of Nusra held hostage of tax arrears since 2010 amounting to Rp21 billion (Direktorat Jenderal Pajak, 2019a). In October 2019, a number of taxpayers were held hostage who had ignored tax arrears of Rp1.68 billion since 2007 (Liputan6.com, 2019). November 2019, the North Sumatra tax authority takes hostage of tax arrears worth Rp1.2 billion (Direktorat Jenderal Pajak, 2019b).

Based on the high phenomenon of tax noncompliance above and is associated with tax sanctions, this study intends to explore how the application of tax sanctions from the perspective of the tax authority. This perspective was chosen because the application of tax sanctions comes from the tax authority. In addition, the approach to taxpayers who have been subject to tax sanctions is very difficult, because it is usually kept secret. Taxpayers who receive tax sanctions are usually only willing to consult with tax consultants. Taxpayers who have received tax penalties will also be monitored by the authorities regarding their compliance in the next reporting period. Therefore, the authorities are well aware of the progress of tax compliance for taxpayers who have received tax sanctions. They also interact directly with taxpayers who are subject to sanctions so they are well aware of the level of tax compliance for taxpayers. In accordance with the objectives of this study, this research can only be approached qualitatively. Research was conducted at the Tax Office (TO) Surabaya Sawahan. This TO applies tax sanctions from administrative sanctions to gizjeling.

This research is different from previous research in several ways. First, previous research related to tax sanctions was approached quantitatively (Doran, 2009; Ermawati \& Afifi, 2018; Newberry et al., 1993; Prihastanti \& Kiswanto, 2015; Rahayu, 2017), while this research is qualitative. Qualitative tax research is available to examine the dimensions of tax fraud (Mangoting \& Sukoharsono, 2017), but no one has focused on perceptions about tax sanctions especially on the gizjeling aspect.

Previous tax compliance studies used questionnaire instruments, thus limiting researchers' direct interaction with informants. As a result, the reality of compliance does not reflect the real conditions experienced by taxpayers. Second, previous research generally focused on the perspective of taxpayers (Istighfarin \& Fidiana, 2018; Napitupulu, 2015; Tobing et al., 2015), This study focuses on tax authorities in order to obtain knowledge of the effects of tax sanctions in improving tax compliance. The supervisory division tax authority is more appropriate to get information on how the behavior of the targeted taxpayer is subject to sanctions including how the taxpayer behaves after being sanctioned as well as other measures related to the imposition of tax sanctions.

\section{RESEARCH METHOD}

This study uses a qualitative approach with an interpretive method that is to interpret the phenomenon of tax sanctions. This approach was chosen to adjust with the research objectives that want to explore the meaning of the application of tax sanctions, which means involving more data in the form of words (Moleong, 2014) and not want to number reality. Qualitative research with interpretive genre does not intend to generalize reality, but rather wants to uncover the uniqueness of reality related to the application of tax sanctions in certain tax authority 
areas which may be the implementation is not exactly the same as tax authorities in other regions.

This research was conducted in the area of the tax authority in Tax Office (TO) Surabaya Sawahan. This Tax Office was chosen because it is one of the major tax authority offices in Indonesia. This TO is a region of Directorate General of Taxes (DGT)East Java 1, which is a contributor to the fourth national tax revenue target in Indonesia (Direktorat Jenderal Pajak, 2016). However, this TO is not included in the list of tax authorities that are able to realize $100 \%$ of the tax revenue target (Asmara, 2018). TO Surabaya Sawahan is one of the TO that has implemented a strategy to pursue tax revenue targets through the application of tax sanctions. Of course, this sanction stage is the last step for taxpayers who have previously been educated or encouraged (Wijayanto, 2019).

In connection with qualitative research, appropriate informants are needed who can provide detailed information about the implementation of sanctions for taxpayers. The informant of this research is the head of the supervision section and the head of the billing section at the TO Surabaya Sawahan. This informant was chosen considering that the Oversight Section and the Billing Section are tax instruments that collect tax receivables and arrears and oversee taxpayer compliance. In addition, this study also utilizes account-representatives as implementing officers who interact directly with taxpayers in terms of tax transactions. Thus, the informants in this study were 3 people, with the initials GT, MT, and SR.

This study uses primary data sources obtained through unstructured interviews with informants. The qualitative data analysis process is interactive and continues until the data is saturated (Miles \& Huberman, 1992). The level of data saturation is marked that researchers are no longer able to obtain new data. The stages of data analysis follow the steps of data reduction, presenting data, and drawing conclusions. The triangulation process also takes place randomly, in which the researcher during the interview process clarifies between sources (informants) and also documents obtained during the research.

Data reduction is done by focusing on data in accordance with the research theme and trimming data that is less relevant. In this way, researchers can arrange patterns of research results based on certain themes. Furthermore, researchers can arrange a series of themes into a flow of discussion relating to the meaning of the application of tax sanctions. Finally, researchers can synthesize or present research findings that might be classified as new and conclude research results.

\section{RESULTS AND DISCUSSION}

In essence, in general human beings are reluctant to pay taxes (Fidiana, 2015). Therefore, it is natural to find the phenomenon of tax noncompliance in any geographic area even though a series of efforts have been made by the tax authorities to boost tax revenue. Some studies of tax non-compliance more often root the problem of tax non-compliance with tax awareness. That is, tax noncompliance is more a matter of awareness, especially related to ignorance of taxpayers that paying taxes is not merely a burden but also has several benefits. Mr. MT emphasized the tax benefits.

"Actually, tax has many uses ... But taxpayers are often not aware of it because they feel there is no direct reward. The most abundant source of income, there must be a contribution to the country for financing purposes. So, good citizens should pay taxes"

Tax compliance is often associated with the principle of burdens and benefits. When people assume that paying taxes does not get any benefit, they are increasingly reluctant to fulfill their tax obligations. The inconsistency of the benefits of paying taxes is the reason for many parties, causing low awareness of taxation (Wahyudi, 2017).

Tax liability is also associated with tax debt. In terms of regulation, taxpayers who are required to pay taxes are bound by having debt to the state. The procedure for collecting debts to the state through taxes is also carried out in stages. As stated in tax regulations and based on the principle of selfassessment system, taxpayers actually have the opportunity to carry out their tax obligations independently without any interruption from the tax authority. The next stage, if the taxpayer turns out to be negligent in fulfilling his tax obligations, the tax authority will perform the function of supervision and control. This function is carried out bearing in mind that the projection of tax funds is funds that the government has hoped to finance the life of the state. This means, if the tax revenue is reduced while the development needs have been budgeted, the tax authority is considered as the party responsible for securing state revenue.

In connection with securing this country, taxes have a compelling nature. In this case the nature of tax coercion arises from the tax status established 
by law. Basically, the taxation law is a guideline for various parties, both for taxpayers in fulfilling their rights and carrying out taxation obligations, as well as for the tax authorities to carry out their duties in collecting state revenue from the tax sector. Triangulation of sources of threats and sanctions for taxpayers is also contained in the regulation, from the lowest to the heaviest sanctions (Rahayu, 2017). Sanctions are imposed for each type of tax violation (Anggarini, Yuesti, \& Sudiartana, 2019; Siregar, 2017). Of course, the imposition of sanctions is carried out carefully after careful examination by the tax authority, as stated Mr. GT and MT in the following,

"In general, tax sanctions have actually been applied since the law was enacted, but the taxation sanctions have been implemented through prior research. So we are careful ... in accordance with the provisions or not. If 'there are indications ... in the form of late reporting, or not reporting in SPT reporting or late payment, we will apply sanctions in the form of Notice of Tax Collecion (NTC) or if' for example NTC cannot be issued then the Notice of Additional Tax Underpayment Assessment. So we still have an application to see whether the taxpayer is late or not. Sanctions are applied since there are tax laws. But it can be charged when it is due which should be a tax debt but instead is not paid".

This statement implies that sanctions can be imposed on taxpayers after documents have been found to indicate tax avoidance. To ensure (triangulation of data and documents) that taxpayers do avoid tax, that tax authorities in the region have reliable application (information technology). Taxpayers who have been declared violating taxes such as late reporting and others, will be sent Notice of Tax Collecion (NTC) the input process is carried out by account representative.

"So we send this Notice of Tax Collecion (NTC) to the taxpayer with a maturity of 1 month from the date of issue and must be paid in nominal terms as stated on the Notice of Tax Collecion (NTC)"

The tax authority then monitors each tax return that is launched. If the taxpayer ignores the Notice of Tax Collecion (NTC) issued by the tax authority, it will be followed by other forms of supervision which of course are also accompanied by sanctions. Actually, before imposing various sanctions as stipulated in the law, the tax authority also runs a guidance program for taxpayers such as counseling.
Sanctions are a last resort after the tax education function has been carried out but taxpayers remain reluctant to obey taxes. Educational functions such as tax counseling are carried out by the authorities and are expected to be effective in promoting taxation and for increasing tax compliance (Prabowo, 2015). Mr. GT and Mr. MT agree to this by stating:

"Of course it's true. So this taxation sanction is one of the means of supervision to increase taxpayer compliance, both from tax compliance and tax reporting. This is one of the repressive means. There is actually more persuasive, persuasive that we issue a letter of appeal. In my opinion, if it is already regulated in a Law then it must be implemented according to the Act. The law itself is not made to harm people, but has the aim to give a deterrent effect".

Mr MT asserted that the function of the tax law is as a guide for tax authorities and taxpayers in carrying out tax obligations. Sanctions are a means of supervision as well as to educate the discipline of taxpayers (Ermawati \& Afifi, 2018; Rahayu, 2017) which is expected to cause a deterrent effect (Masruroh, 2013). This firmness confirms the appropriateness of tax authority practices in applying sanctions (triangulation of data sources).

Thus, the imposition of sanctions can be used for two purposes, namely to educate and to punish. The purpose of educating is intended that after being sanctioned it is expected that taxpayers can know their obligations better. While the purpose of punishment is to cause a deterrent effect (Prabowo, 2015). The purpose of this sanction turned out not only at the level of regulation, but also the realization of authority as follows.

"Our view is twofold. The first side is the effect on taxpayers, the second is from policing ... because there are many taxpayers ... so we rely on the system, so we research to issue STPs through the system. This means we are trying to be as fair as possible to implement tax penalties for taxpayers who do not carry out their obligations. The second effect ... of course we provide justice for taxpayers who have reported in accordance with the rules and also taxpayers who have not reported ... this is one of the principles of fairness of tax officials to apply the law".

So, the application of tax sanctions is actually for the purpose of upholding justice. That is, the imposition of sanctions is justice for taxpayers who 
have been orderly and obedient to pay taxes. The determination of the tax sanctions is also not sudden, but through a series of research processes by the authorities.

"Of course we first look at the procedure, meaning that the terms that can be in STP are anything ... it is in the realm of research. After the research fulfills that he is sanctioned, we publish it. We do not see who the taxpayers are, what is certain is that if they do not implement the provisions of the tax legislation, we will impose sanctions".

Mr GT's statement contained two things, firstly related that the determination of Notice of Tax Collecion (NTC) always followed the research procedures. Second, the determination of tax sanctions is not based on the subject of taxes but based on the principle of justice. Similar to this phenomenon, some studies also mention that tax sanctions are applied indiscriminately and that sanctions must be applied fairly in accordance with the level of taxpayer violations (Syakura \& Baridwan, 2014). So, the determination of sanctions is also carried out in stages from the mildest sanctions to the most severe ones. The lightest sanctions are appeals and the heaviest sanctions in the form of gizjeling.

The stages of tax sanctions in accordance with tax regulations generally include appeals in the form of Notice of Tax Collecion (NTC), warning letters, forced letters, account blocking, assets confiscation, prevention of taxpayers fleeing abroad, seized confiscated assets, and gizjeling. Tax collection itself includes two 2 (two) types, namely passive billing and active billing. In passive billing, tax officers or tax authorities make persuasive appeals through telephone media and letters sent to taxpayers. On passive billing, the tax authorities only inform taxpayers of the tax debt that must be paid. If persuasive appeals are not responded to by taxpayers, then it can proceed to repressive billing in the form of inspection efforts (Prihastanti \& Kiswanto, 2015). This appeal was followed by administrative sanctions if taxpayers were reluctant to respond.

... if the appeal does not work does not mean it is not responded then we will issue administrative sanctions.

The implementation of tax sanctions is implemented first in the AR (Account Representative) work unit, through a series of application-based research processes, namely Information Systems Directorate General of Taxes (ISDGT). This system will detect taxpayers' negligence in fulfilling their tax obligations as stated by SR.

"We have a ISDGT application system to monitor and conduct research related to negligent taxpayer information in paying taxes including other violations. This system also accommodates the calculation of tax penalties and tax debt that must be paid".

Based on the output of the report obtained from ISDGT, AR will compile a description of the research, calculation sheet and sheet for Tax Invoice. Furthermore, the document will be forwarded to the system and hardcopy to the service section. The service section then issues a Tax Collection Letter that is a legal product of administrative sanctions. This Notice of Tax Collecion (NTC)is then sent to taxpayers by post and copies are sent to the billing section as a basis for billing.

Notice of Tax Collecion (NTC) is not just a media for tax collection but is also used by the authority of each tax area to pursue the target. This was stated by Mr. GT,

"For Notice of Tax Collecion (NTC) publishing in the section related to AR, the target is indeed applied. So in one year it is at least how much, of the amount not looking at nominal. This means how many STPs have been issued. We don't see the nominal value, because this is related to the main performance indicators of the duties of an Account Representative"

Notice of Tax Collecion (NTC) is an indicator of the performance rating of Account Representatives (AR). So, AR which is an officer who serves taxpayers also calculated their performance based on tax targets that can be generated. If this target does not achieve what is expected, a number of tax collection strategies will be implemented so that it can cover the tax target. The tax target burden on this $\mathrm{AR}$ unit is the realization of tax regulations that AR carries out the supervisory function and explores the potential of taxpayers. AR is even a unit that interacts directly with taxpayers in carrying out the task of securing state revenue through tax targets. It can be understood that the position of AR as a bridge between the tax authority and the taxpayer (Puspasari et al., 2011). Tax collectibility thus also depends on AR's professionalism in providing services as well as carrying out the supervisory function of taxpayers. Naturally, AR's performance 
can be examined through the achievement of tax targets, one of which is the number of STPs issued and not the nominal value. Conformity between realization and target will show Account Representative Performance indicators, as shown in the following table,

Table 2. Publishing Notice of Tax Collection (STP)

Tax Office of Surabaya Sawahan Year 2016-2018

\begin{tabular}{ccc}
\hline Tax Year & Amount of STP & Rp \\
\hline 2016 & 8,374 & $65,012,455,419$ \\
2017 & 8,271 & $46,015,179,891$ \\
2018 & 9,167 & $11,613,968,682$ \\
\hline
\end{tabular}

Source: Billing Unit of Tax Office of Surabaya Sawahan, 2018

The number of tax bills in 2016 to 2017 has decreased. It can be summarized that this year there was an increase in tax compliance as evidenced by the decrease in the number of Notice of Tax Collecion (NTC). This decrease is partly due to the fact that in 2017 it was a tax amnesty period so that the authorities increased their tax targets in the tax amnesty program, not the Notice of Tax Collecion (NTC). This tax amnesty program continues until 2018 so that the number of Notice of Tax Collecion (NTC)s has increased dramatically, as a result of supervision of taxpayers who have participated in tax amnesty. The tax amnesty program must indeed be recognized as having boosted a fairly high tax target even though its main target related to overseas taxpayer assets has not been touched.

Notice of Tax Collecion (NTC) implementation is not always smooth as expected. Some obstacles to realize Notice of Tax Collecion (NTC) include the lack of knowledge from taxpayers (Caroko, et al., 2015; Nugroho et al., 2016). Many taxpayers feel they don't know about the STP so when they receive the STP they blame the tax officer for the burden of sanctions that must be paid. They generally demand to get tax education before they are willing to pay tax penalties. The lack of tax knowledge is indeed recognized by Mr GT.

“... the problem is that when we later issue Notice of Tax Collecion (NTC)s, it turns out that they feel they don't know, even though it is clear that the tax obligation is actually self-assessment, so the taxpayers themselves should find out. The tax office as a facilitator, we provide socialization and so on, but many taxpayers blame us for it. This taxation knowledge is an obstacle but it is also a challenge for us to increase taxpayer knowledge about their obligations from starting to calculate, report, deposit."
Self assessment apparently has not yet been rooted in taxpayer awareness. It could be that indeed many Indonesians do not know about their rights and obligations as taxpayers except for those who have studied tax. While not all people learn tax and taxes are not the contents of the learning curriculum in both secondary and tertiary education except in majors related to tax. So, naturally many taxpayers who complain do not understand tax but are asked to fulfill tax obligations properly and correctly. This is recognized by the tax authority.

"If in Sawahan Tax Office many taxpayers do not know the obligation to report, so most of the sanctions are for reporting tax returns ... because they don't know, even though at the beginning of the TIN (Taxpayer Indentification Number) registration we had been helped by an officer at the help desk who provided what are their obligations, be it individuals or bodies. If an 'individual reports the Annual Tax Return, if' the Annual Tax Return and the Annual Tax Return and so on.

The lack of knowledge about taxation rights and obligations has been tried to overcome by providing provisions to taxpayers when they register TIN (Taxpayer Identification Number). However, this obstacle does not necessarily overcome, because tax obligations usually exist at the end of the tax year. So the time lag between obtaining TIN with reporting is quite far, which resulted in many taxpayers who have forgotten. How is it possible that taxpayers can carry out taxes obediently, if information is due and how to calculate and report taxes, they don't understand (Mangoting \& Sukoharsono, 2017).

The tax regulation has actually demanded and even forced that taxpayers must meet tax obligations. This obligation implies that regulations never want 
to know whether people understand tax regulations. Implicitly means that if the taxpayer wants his tax obligations to be reported correctly, it means that the taxpayer is required to study tax. Not surprisingly, if eventually taxpayers recruit tax experts or hire tax consultants to meet their tax obligations. Related to the lack of tax knowledge, the authorities routinely carry out tax socialization, especially nearing the tax reporting period, known as annual tax returns.

"Every year we certainly do socialization, both socialization about reporting Annual Tax Return, Annual Tax Return and other tax obligations. That's where we try to provide knowledge to taxpayers that they have an obligation to report, deposit and calculate. The ingredients are socialization, giving pamphlets. Usually we give socialization to the villages. Because there are three of our territories ... So every year we certainly provide information to taxpayers in these three villages".

The tax authorities have carried out various ways of socializing both through radio broadcasts, banners, pamphlets which aim to remind tax obligations. So, the authorities are also not passive and leave the taxpayers in ignorance, but they still carry out the education and service functions to taxpayers who need it.

Second, the tax address constraints moved or fake taxpayer. NTC is always sent via post, but often returns because the address is not found or because most (70\%) of taxpayers in Surabaya Sawahan Tax Office are individuals or employees so that it is prone to change of address and move to work agencies. This makes it difficult for tax authorities to submit tax sanctions.

“... because taxpayers employees are usually not in his place of residence. Most of them report the obligation to forget. So the challenge is we can give letters to taxpayers and get them read by taxpayers. Most of them don't come here, because they only address here and they don't have address updates, because in the past they might have reported it from the old office and then they moved. Finally, the NPWP remained unchanged, so we sent the letter, and it didn't arrive. So the obstacles may be from conformity with the latest taxpayer address".

Change of address that is not accompanied by reporting to the tax authority, causing the authority not to get the latest information about taxpayers. Thus, the STP submitted also returned and consequently the authorities also lost the opportunity to obtain tax revenue, especially if it was clearly caused by a change of address. Such matters have been overcome by the authorities through several agenda of activities as told by Mr GT.

"Every year there must be such a thing as a work visit to the taxpayer. If 'for example we continue to return taxpayers, we try to make a visit to the location or address of the taxpayer. If 'for example does not exist or has not been found, then we try from what has been reported by the taxpayer, be it a NIK attachment or workplace ... We have an application to see by entering the NIK it can see the last address where. So we have an online data of Citizen Identification Card at the Directorate General of Taxes".

Notice of Tax Collecion (NTC)s that do not arrive at the destination address are followed up by officers by visiting or visiting the location of the taxpayer address. Furthermore, if it is true that the taxpayer has moved or is not found, the authorities are tracking the whereabouts of the taxpayer through the available application.

If passive billing efforts do not produce significant results that can increase tax revenue, especially in achieving the target, the authority will make repressive and active billing efforts in accordance with applicable tax regulations. This refers to tax regulation 561/KMK.04/2000 which legalizes the tax authority to collect taxes through warning letters/ warning letters to seizure/auction actions. So, the nature of active billing is enforcement. Thus, an active billing effort is guarded by a law that allows authorities to take certain actions to taxpayers.

The stages in this active billing effort begin with the issuance of Tax Assessment in the form of Notice of Tax Collecion (NTC), Notice of Tax Underpayment Assessment (NTUA), and Additional Notice of Tax Underpayment Assessment (ANTUA). This bill has a maturity period of 1 (one) month since it was issued. If the tax debt is not paid up to 7 (seven) days from the due date, a Warning Letter will be issued.

Letter of reprimand that is not responded to until 21 (twenty one) days from the date of the letter of reprimand is submitted, a Forced Letter is issued which is delivered directly by the Taxpayer. This forced letter requires taxpayers to pay off their tax 
debt with a $2 \times 24$ (twice twenty-four) hours. Furthermore, if within the said time period there is no tax settlement, a Confiscation Order will be issued. This action refers to Law No. 19 of 1997 concerning Tax Collection by Forced Letter. Then, the auction announcement will be made if the taxpayer has not paid off his tax debt up to 14 (fourteen) days from the date of the Order of Foreclosure and continued with the execution of the auction if within 14 (fourteen) days after the announcement of the auction is not paid. Confiscation and auction are not the main objectives of the tax. The tax regulation wants a tax payment target. If the proceeds from the confiscation and auction of the taxpayer's assets are not sufficient to pay the tax debt, then the next effort will be carried out namely gijzeling.

Gijzeling is the last way the tax authorities do to collect tax debt. Gijzeling uses three stages: first, sending a copy of a forced letter and a warrant for confiscation to the bank to block the account. Second, blocking taxpayers so they do not flee abroad. Third is gijzeling or forced body for a period of time for 6 (six) months, and can be extended 6 (six) months later as stated by Mr MT.

"... detained for 6 months can be extended for another 6 months ... we are released but the tax debt does not expire, so it must be paid, so the bailiff will look for assets everywhere.."

6 (six) months detention plus 6 months later tax collection is still carried out by confiscating assets owned by the taxpayer. So, even though physically not being held in other words, it is released, but the tax debt is not forfeited. So, every act of tax enforcement based on law enforcement aims to realize tax revenue. This means that the physical arrest of taxpayers is not the main purpose of the tax, because the priority is still aimed at increasing state revenue. Therefore, taxpayers who have exceeded the period of physical detention (physical hostages) will still be billed, not abolishing their tax obligations. The purpose of the physical hostage is to shame the tax guarantor so that he is willing to pay off his tax debt and no more assets are hidden. However, if during the detention period the tax guarantor can pay off his tax debt, the tax guarantor can be directly released (Ispriyarso, 2015; Tobing et al., 2015).

The hostage practice of gijzeling cases was carried out against taxpayers in Bandung in 2017 (Ispranoto, 2017). The Tax Office of South
Karawang South took hostage of the chief director and commissioner of PT CTM for having a tax arrears of Rp1.9 Billion. The two leaders were held hostage in the Class IIA prison in Karawang. This gijzeling action seems right on target, because the taxpayers immediately pay off their tax arrears so that they can be immediately released. In fact, before being dealt with gijzeling, both of them have been billed persuasively through letters of reprimand, forced letters, seizure orders, account blocking, and prevention to go abroad from 2013 to 2017. Both of these taxpayers still have not shown the intention to pay taxes so that the last attempt in the form of gijzeling must be carried out. So, gijzeling does have a deterrent effect for taxpayers. In addition, by gijzeling, it can save state revenue which is indeed the main goal of tax collection.

Thus, gijzeling is applied in order to remind taxpayers that taxes have legal force that is coercive. This repressive nature is also carried out selectively and prioritizes prudential aspects. Gijzeling cannot be realized immediately until there is a previous billing process and added with strong supporting evidence. Taxpayers who have received gijzeling sanctions are also kept confidential, related to the principle of tax authorities in maintaining the confidentiality of taxpayers.

This gijzeling strategy has also been applied at Tax Office Surabaya Sawahan to one of the taxpayers based on what Mr MT,

"There is no WP imprisoned, but we have a target in gijzeling, namely in one year there are two. But seen if the taxpayer is still in compliance, then it will not get to prison. This means that the taxpayer has good intentions to make installments on his tax debt, and it must be kept in mind also on these installments the interest of $2 \%$ per month, well that we consider obedient. But if it's not like paying taxes, but where to go around in jail, then".

Tax authorities prefer paying off tax debts, not penalizing taxpayers. Gijzeling is only a way to force taxpayers to pay off their tax obligations either by being paid at once as well as by paying in installments and even being delayed. This method is in line with the mandate of the Minister of Finance (Regulation of the Minister of Finance) number 242/PMK.03/ 2014 concerning Procedures for Payment and Tax Payment (triangulation of data sources). What needs to be emphasized is that the delay in repayment is subject to an interest sanction of $2 \%$ (two percent) 
per month. Taxpayers who show good faith to settle this tax debt will not receive gijzeling sanctions. So, gijzeling was chosen by the authorities as a last resort for taxpayers who have the ability to pay off tax debt but are reluctant and do not show good faith.

In connection with the billing efforts described above, it can be concluded that as long as the administrative sanctions imposed have been paid by the taxpayer there will be no further action, because in the case of imposing criminal sanctions, the state is also minimized, considering the purpose of the tax law is in principle not to convict a taxpayer but so that tax money can be realized as state revenue (Wijayanto, 2019).

The state indeed differentiates tax sanctions into two. First, violations related to tax administration will be subject to administrative sanctions in the form of interest and penalties. The method for billing is the mechanism of Tax Assessment Letter or Tax Collection Letter. Second, criminal offenses will deal with criminal sanctions. Authorities are more concerned with efforts to maintain revenue from the state so that persuasive efforts are preferred and take precedence over repressive efforts.

Each tax authority office is burdened with different tax revenue targets adjusted to the tax conditions and potential in each region. The performance of each authority area is assessed based on the revenue target compared to the realization or achievement of the revenue target.

The mandate of tax revenue targets in each region always increases every year. It can be understood that the prices of goods and services (income) of the people are also on an upward trend. It's normal if the tax target also increases. Because the increase in tax targets is not always directly proportional to the level of tax compliance. Various tax compliance data as explained at the beginning is in the opposite position, which is decreasing. To pursue the tax target, the tax authority must explore new tax potentials in the area or impose sanctions on taxpayers who are identified as not compliant. The success of realizing the tax target including from the source of tax sanctions is thus an effort of the authorities to prove their work performance. Without an increased target demand, it could be that the tax authorities are not up to taxing from the source of sanctions. So, one of the objectives of sanctions is to benefit the performance or performance of the tax authority. The performance of the Tax Service Office is assessed by comparing previous achievements
(Puspasari et al., 2011; Tobing et al., 2015) or compare with targets set by the government.

Charges for tax sanctions are carried out by issuing NTCs by the Account Representative. Surabaya Sawahan Primary Tax Office also seeks to realize the target of tax receivable disbursement. The realization of tax receivables is also an indicator of the achievement of the performance of the tax authority. Its performance is measured through the realization of the disbursement of receivables due to the provisions which are past due and the billing actions that have been carried out by the billing section. Regarding this target for disbursing receivables, Mr. MT said that Tax Office Surabaya Sawahan in 2016 was able to realize all tax receivables,

“... which has a target for disbursing receivables in which there is a tax on the sanction itself. Now for the realization of disbursement of these receivables reached $100 \%$ ".

In 2017 and 2018, the achievement of tax receivables realization was not as good as 2016 . This indicates that there are still tax receivables that have not been paid by taxpayers. Mr. MT stated that uncollectible tax receivables face obstacles in the taxpayer's willingness,

"There are no obstacles to implementation, the problem is that it is already based on the law ... human resources also already exist, then the online system is also complete, so it can track all the identities of taxpayers. Maybe there are obstacles on the part of taxpayers why they don't want to pay, are late, and so forth"

It is not the tax system or the performance of the authority that is the obstacle, but the negligence of taxpayers which is the main obstacle in the realization of tax receivables. Tax authority personnel have tried to carry out their duties properly and responsibly and are supported by a taxation system which is now also easy through the online system. In general, efforts to achieve performance and achievement of achieving tax targets must deal with taxpayers who are reluctant to meet tax obligations and even tend to avoid taxes.

\section{CONCLUSION}

This study aims to determine the application of tax sanctions at the Tax Office Surabaya Sawahan as an effort to improve tax compliance. Based on a 
qualitative approach, this study found that the tax authority views tax sanctions as a means of supervision to improve taxpayer compliance and to create a deterrent effect. This sanction is applied to all taxpayers who violate and carried out indiscriminately. The application of tax sanctions in Tax Office Surabaya Sawahan refers to the procedures and applicable laws. This can be seen from the process of determining the sanctions in stages, starting from the issuance of appeals to issuing Notice of Tax Collecion (NTC), followed by active billing, which starts from reprimand to hostage or gijzeling as a final effort. The application of tax sanctions can be divided into administrative sanctions and criminal sanctions. Administrative sanctions include fines and interest, while criminal sanctions are realized in the form of gijzeling. Notice of Tax Collecion (NTC) is a legal product of administrative sanctions. Based on the increasing Notice of Tax Collecion (NTC) data, it is concluded that the level of tax compliance in the Surabaya Sawahan Primary Tax Office is still relatively low, as evidenced by the number of taxpayers who submit Annual Tax Returns (ATR) is smaller than the number of taxpayers who are obliged to ATR. The application of tax sanctions still prioritizes administrative sanctions, while criminal sanctions are chosen as a last resort if taxpayers are able to pay tax debt but have not shown good faith to pay off their obligations. This means that the tax authority in Tax Office Surabaya sees taxes as a function of the budget or a source of state revenue. The function of tax as a regulator or regulator is not ruled out, but because the main purpose of taxes is to save state money and not to criminalize taxpayers, criminal sanctions are applied carefully and selectively.

This research has several weaknesses, mainly because the researcher is an external party who is not directly involved in implementing tax sanctions. Research on tax sanctions will be more detailed if it is set forth by the authorities. This is related to not all tax information can be published relating to the confidentiality aspects of taxpayers. This research was also not developed from perspectives outside of tax employees such as academics and tax observers so that it can be used as material for the development of studies in subsequent studies.

\section{REFERENCES}

Anggarini, L. P. I., Yuesti, A., \& Sudiartana, I. M. (2019). Pengaruh Penerapan Kebijakan Tax
Amnesty, Pengetahuan Perpajakan, Kesadaran Wajib Pajak, Dan Sanksi Perpajakan Terhadap Kepatuhan Wajib Pajak Orang Pribadi Di Kantor Pelayanan Pajak Pratama Denpasar Timur. Jurnal Riset Akuntansi Juara, 9(1), 48-61.

Ariani, M., \& Utami, T. E. (2016). Pengaruh Pelayanan Aparat Pajak, Modernisasi Sistem Administrasi Perpajakan Dan Sanksi Pajak Terhadap Motivasi Wajib Pajak Orang Pribadi Dalam Membayar Pajak Penghasilan. Tekun: Jurnal Telaah Akuntansi Dan Bisnis, 7(1), 1-22. https://doi.org/http://dx.doi.org/10.22441/ tekun.v7i1.655

Asmara, C. G. (2018, December 19). Cuma 15 Kantor Pajak yang Sudah Capai Target 100\% Penerimaan. CNBC Indonesia. Retrieved from https://www.cnbcindonesia.com/news/ 20181219122018-4-47076/cuma-15-kantorpajak-yang-sudah-capai-target-100-penerimaan Cahyadini, A., Arta Atmaja, B., \& Oka Margana, I. (2017). Pembaharuan Sanksi Pajak Sebagai Upaya Mengoptimalkan Penerimaan Negara. Veritas et Justitia, 3(2), 494-518. https://doi.org/ 10.25123/vej. 2776

Caroko, B., Susilo, H., \& Z, A, Z. (2015). Pengaruh pengetahuan perpajakan, kualitas pelayanan pajak, dan sanksi pajak terhadap motivasi wajib pajak orang pribadi dalam membayar pajak. Jurnal Perpajakan.

Direktorat Jenderal Pajak, D. (2016). Surabaya Terus Upayakan Seratus Persen. Direktorat Jenderal Pajak Kementrian Keuangan. Retrieved from https://www.pajak.go.id/id/ surabaya-terus-upayakan-seratus-persen

Direktorat Jenderal Pajak, D. (2019a). Kanwil Nusra Bebaskan Sandera Penunggak Pajak 21 Miliar. Retrieved from https://www.pajak.go.id/ id/berita/kanwil-nusra-bebaskan-sanderapenunggak-pajak-21-miliar

Direktorat Jenderal Pajak, D. (2019b). Kanwil Pajak Siantar Sandera WP Tak Patuh Berujung Pelunasan. Retrieved from https://pajak.go.id/ id/siaran-pers/kanwil-pajak-siantar-sandera-wptak-patuh-berujung-pelunasan

Doran, M. (2009). Tax Penalties and Tax Compliance. Harvard Journal on Legislation, 46, 111-161. Retrieved from https://scholarship. law.georgetown.edu/facpub/915http://ssrn.com/ abstract $=1314401 \mathrm{https}: / /$ scholarship.law. georgetown.edu/facpub 
Ermawati, N., \& Afifi, Z. (2018). Pengaruh Pengetahuan Perpajakan dan Sanksi Perpajakan terhadap Kepatuhan Wajib Pajak dengan Religiusitas sebaga Variabel Pemoderasi. SENDI. Kudus: Universitas Muria Kudus.

Fidiana, F. (2015). Kepatuhan pajak dalam perspektif neo ashabiyah. Ekuitas, 19 No. $2 J$ (Juni), 260-275.

Ispranoto, T. (2017). Sempat Disandera, Penunggak Pajak Bebas Setelah Lunasi Rp 1,9 M. Detik Finance.

Ispriyarso, B. (2015). Sandera Pajak Sebagai Alat Paksa Dalam Penagihan Utang Pajak. Masalah-Masalah Hukum, 44(1), 69-77. Retrieved from https://ejournal.undip.ac.id/ index.php/mmh/article/view/11425/9682

Istighfarin, N., \& Fidiana, F. (2018). Tax Amnesty dari Perspektif Masyarakat Pajak. AKRUAL: Jurnal Akuntansi, 9(2), 142. https://doi.org/ 10.26740/jaj.v9n2.p142-156

Lederman, L. (2005). Tax Compliance and the Reformed IRS. Kansas Law Review, 51(9711111). https://doi.org/10.2139/ssrn.391134

Liputan6.com. (2019, October 29). DJP Jatim I Sandera Penunggak Pajak Surabaya Rp 1,68 Miliar. Liputan6.Com. Retrieved from https:// surabaya.liputan6.com/read/4098176/djp-jatimi-sandera-penunggak-pajak-surabaya-rp-168miliar

Mangoting, Y., \& Sukoharsono, E. G. (2017). Menguak dimensi kecurangan pajak. (121), 274-290.

Manurung, S. (2013). Kompleksitas Kepatuhan Pajak. Direktorat Jenderal Pajak Kementrian Keuangan.

Masruroh, S. (2013). Pengaruh Kemanfaaatan Npwp, Pemahaman Wajib Pajak, Kualitas Pelayanan, Sanksi Perpajakan Terhadap Kepatuhan Wajib Pajak (Studi Empiris Pada WP OP Di Kabupaten Tegal). Diponegoro Journal Of Accounting, 2(4), 1-15. Retrieved from http://ejournal-s1.undip.ac.id/index.php/ accounting

Miles, B. M., \& Huberman, M. (1992). Analisis Data Kualitatif. Jakarta: Raja Grafindo.

Moleong, L. (2014). Metode Penelitian Kualitatif (Edisi Revi). Bandung: PT Remaja Rosdakarya. Napitupulu, I. K., Zirman, Z., \& Azlina, N. (2015). Analisis Himbauan, Pemeriksaan, Dan Tindakan Penagihan Aktif Terhadap Realisasi Penerimaan Lima Klasifikasi Lapangan Usaha (KLU) Dominan (Studi Kasus KPP Madya Pekanbaru).
Jom Fekon, 2(1), 1-13. Retrieved from https:// jom.unri.ac.id/index.php/JOMFEKON/article/ view/5643/5519

Nar, M. (2015). The effects of behavioral economics on tax amnesty. International Journal of Economics and Financial Issues, 5(2), 580-589.

Newberry, K. J., Reckers, P. M. J., \& Wyndelts, R. W. (1993). An examination of tax practitioner decisions: The role of preparer sanctions and framing effects associated with client condition. Journal of Economic Psychology, 14(2), 439452. https://doi.org/10.1016/0167-4870(93) 90010-I

Ningrum, D. K., \& Ispiyarso, B. P. (2016). Kebijakan Formulasi Hukum Pidana Di Bidang Perpajakan Sebagai Upaya Peningkatan Penerimaan Negara. Law Reform, 12(2), 209. https://doi.org/ 10.14710/lr.v12i2.15875

Nugroho, A., Andini, R., \& Raharjo, K. (2016). Pengaruh Kesadaran Wajib Pajak Dan Pengetahuan Perpajakan Wajib Pajak Terhadap Kepatuhan Wajib Pajak Dalam Membayar Pajak Penghasilan. Journal Of Accounting.

Prabowo, A. (2015). Efektivitas Sosialisasi Perpajakan Terhadap Kepatuhan Pelaporan Spt Tahunan Wajib Pajak Orang Pribadi Pada Kantor Pelayanan, Penyuluhan, Dan Konsultasi Perpajakan (Kp2Kp) Tondano. Jurnal Riset Ekonomi, Manajemen, Bisnis Dan Akuntansi, 3(1), 1063-1070.

Prihastanti, R., \& Kiswanto. (2015). Tingkat Kepatuhan Wajib Pajak Badan terhadap Penerimaan Pajak Dimoderasi oleh Pemeriksaan Pajak. Accounting Analysis Journal, 4(1), 1-9. https://doi.org/10.15294/ aaj.v4i1.7837

Puspasari, I. D., Puspita, E., \& Paramitha, D. A. (2011). Account Representative sebagai Jembatan Kepatuhan Pajak? Jurnal Jibeka, 11(1), 9-17.

Rahayu, N. (2017). Pengaruh Pengetahuan Perpajakan, Ketegasan Sanksi Pajak, dan Tax Amnesty terhadap Kepatuhan Wajib Pajak. Jurnal Akuntansi Dewantara, 1(1), 15-30.

Siamena, E., Sabijono, H., \& Warongan, J. D. L. (2017). Pengaruh Sanksi Perpajakan Dan Kesadaran Wajib Pajak Terhadap Kepatuhan Wajib Pajak Orang Pribadi Di Manado. Jurnal Riset Akuntansi Going Concern, 12(2), 917-927.

Siregar, D. L. (2017). Pengaruh kesadaran wajib pajak dan sanksi pajak terhadap kepatuhan wajib 
pajak orang pribadi pada kantor pelayanan pajak pratama batam. Journal of Accounting \& Management Innovation, Vol.1 No.2, July 2017, Pp. 119-128, 1(2), 119-128.

Syakura, M. A., \& Baridwan, Z. (2014). Determinan Perencanaan Pajak dan Perilaku Kepatuhan Wajib Pajak Badan. Jurnal Akuntansi Multiparadigma, 5(2), 185-201.https://doi.org/ 10.20476/jbb.v16i2.610

Tobing, G. C., Khairani, D., \& Mukarromah, A. (2015, February). Gijzeling: Akankah Memberi Efek Jera dan Mendorong Kepatuhan? Inside Tax
Media Tren Perpajakan, 5-10. Retrieved from https://ddtc.co.id/uploads/pdf/InsideTax-28thEdition.pdf

Wahyudi, H. (2017). Jurnal Studi Akuntansi \& Keuangan. Jurnal Studi Akuntansi \& Keuangan, 1(1),39-52.https://doi.org/105281/zenodo.1098485

Wijayanto, W. (2019, May 18). Realisasi Penerimaan Pajak Naik 16,4 Persen. Radar Surabaya. Retrieved from https://radarsurabaya.jawapos. $\mathrm{com} / \mathrm{read} / 2019 / 05 / 18 / 137740 /$ realisasipenerimaan-pajak-naik-164-persen 